Vol. 2 No. 3, 2021

\title{
THE BLUE ECONOMY: A NEW TREND IN SOCIAL DEVELOPMENT
}

\author{
Mykhailo Sverdan ${ }^{1}$
}

\begin{abstract}
The purpose of the paper is to study the current problems of ecology and environmental protection, which is associated with modern sustainable trends in economic development. The growth of the world economy as a whole and the economic progress of most developed market economies is leading to increased use of natural resources and, at the same time, to increasing depletion and pollution of the environment. The purpose is to define the essence, the prerequisites for the emergence and development of the blue economy as a modern concept of interaction between society and nature through the economy, as well as to reflect the preconditions for the activation of a common green movement on a global scale in order to preserve nature and ensure the natural conditions of human habitation. The topic of the article is due to the need to disclose the current economic dynamics and the pace of social progress and its impact on the environment. In this regard, the essence of the blue economy, directions and principles of its implementation for the restoration and strengthening of natural potential are considered. Methodology. An objective and adequate assessment and analysis of the dynamics and directions of the world economy in terms of increasing economic potential and the production of economic goods to ensure the well-being of society makes it possible to properly assess the level of impact on nature and the environment. The results of such assessments and calculations make it possible to identify and correct existing and prevent the occurrence of potential errors in the choice of priorities for socio-economic policy and in making effective decisions in the sphere of production. The study is based on an assessment of the interaction between the economy and the environment at the present stage of civilizational progress. Results. The issues of modern economic trends and the environment and ecology are investigated. The essence, specificity and necessity of introducing the blue economy in modern conditions are defined. The need to protect nature and reduce pollution is becoming more and more relevant to modern society. Practical implications. The state of the natural environment and the possibilities of saving and improving it are studied. An adequate assessment of the state of nature and natural resources will allow the global community to conduct a balanced and effective socio-economic and environmental policy for the harmony of society and the nature in which it lives. Value/originality. It has been established that nature is the basis of the social and economic life of society and at the same time the primary goal of the progress of civilization. Economics is simply the means by which nature enables the creation of wealth for society. Nature can exist without humanity, but humanity cannot exist without nature. That is why the primitive form of nature and a clean environment is especially relevant, particularly in today's environment. To this end, a new type of environmental policy as the "blue economy" has begun to be introduced in the modern world.
\end{abstract}

Key words: economy, nature, civilization, ecology, environment, development.

JEL Classification: 010, Q50

\section{Introduction}

Modern civilization is very concerned about the significant deterioration of the environment. The study of anthropogenic impact on nature has shown that a change in the process of human activity of only one natural component can lead to the disruption of many ecological systems and not only in the area of direct human activity.

Corresponding author:

${ }^{1}$ National University of Life and Environmental Sciences of Ukraine, Ukraine

E-mail: sverdanof@ukr.net

ORCID: https://orcid.org/0000-0002-1773-3919
Today, there is practically no human impact on nature, the consequences of which would not be influenced by nature.

The existence of mankind is related to its activities. Any productive activity necessarily involves an impact on the environment, but this impact may be less or more significant. By saving on environmental costs, humanity ends up suffering 
losses due to environmental degradation. All changes in nature occur according to the principle of a chain reaction, when one disturbance causes others, which often occur with great acceleration.

The different types of anthropogenic impacts cause certain consequences, which can be divided into the following groups:

1) deterioration of the quality of life (increased morbidity, mortality, worsening recreation conditions, etc.);

2) reduction in the service life of property (fixed assets, etc.);

3) increase in the concentration of harmful substances in the air, water, and soil;

4) decrease in agricultural crop yields, growth of biomass in forestry.

Research into the study and prediction of the consequences of irreversible and increasing processes of destruction of the "sphere of life" states that it is no longer possible to solve the problems created by humanity over the millennia by developing and implementing environmentally friendly and resource-saving technologies. This is due to the demographic explosion and increasing urban needs of people, the total amount of natural products consumed by mankind has increased by tens and hundreds of times. At the same time, the possibilities of nature are exhaustible.

Many studies state that over time the state of the environment is steadily deteriorating, raw material and energy resources are being depleted, the proportion of arable land and fresh water is decreasing, as well as old and new large-scale problems are exacerbated. This is accompanied by a rise in general poverty, a growing stratification of poor and rich nations and nations, and the degradation of all spheres of social life. In a world divided into rich and poor, there is a continuous struggle for the distribution of natural resources, which is becoming increasingly large-scale and in the near future may even turn into an intraspecific struggle for existence.

The urbanistic way of development of science and technology, determined by the consumer interests of society, and therefore focused only on the growth of production capacity and economic growth, is unpromising and leads to an all-round exacerbation of the ecological crisis. Therefore, a new world-view must gradually be laid in the basis of humanity's nature management activities.

There are sharp contradictions between traditional economic and ecological needs. They lie in the fact that traditional approaches to assessing economic efficiency require a return on investment as soon as possible, and environmental requirements dictate the need for long-term investments, the payback period of which does not comply with the rules of traditional economics.

It is necessary to remember that by destroying nature, humanity will perish. Nature can exist without man, but man cannot exist without nature.

\section{The concept of the blue economy}

Several decades ago the world's leading economists proposed a model for the sustainable development of society. Many developed countries have developed and adopted the concept of sustainable development in the context of this model. At the end of the twentieth century, ideas of a green economy as an ascending economic development of society without ecological change using renewable technologies, energy sources and raw materials began to be intensively introduced into economic theory. At the same time, it is believed that the "green" economy model is too expensive and not adapted to modern economic realities. It is more romantic than practical, because it requires considerable financial expenses, which only developed countries can afford. For example, the idea that anyone would be willing to pay more for an end product for the sake of reducing carbon emissions is questionable, especially considering that one and a half billion able-bodied people on Earth do not have stable jobs and incomes. Also, replacing toxic industries with less toxic ones is an example of the lesser evil theory. Billions of dollars of investment in less toxic and more energy-efficient batteries continues to be based on the mining, metallurgical, and chemical industries. Even less toxic batteries, having reached the end of their life, must be recycled or stored in landfills in the environment, posing a long-term risk to humans. The paradox of the green economy is that production structures receive environmental rewards for reducing emissions, even if they continue to pollute.

It's time to move to a competitive business model that allows manufacturers to offer better products at lower prices while innovating in ways that not only increase profits, but also benefit the environment. This economic philosophy is called the "blue economy" (Pauli, 2010). Today, the blue economy is a theory supported by more than 180 concrete projects already implemented, 
which show that with less investment you can make more money, create new jobs and compete in the global market (Brears, 2021). The essence of the blue economy, in which the main criterion of the results of industrial activity, unlike the traditional economy, is not profit, but a comprehensive environmental and economic effect. The blue economy is based on the understanding of the logic of the development of natural systems, their balance, which go beyond the usual conservation of resources. The blue economy goes beyond the green economy, based not only on protecting and restoring nature, but also on developing natural systems as a whole. In the blue economy, sustainable efficiency is achieved by replacing what does not require the development of new industries, it offers a significant number of new jobs, valuable products, and social justice (Nash, 2018).

The blue economy is based on certain principles, the main one of which is the cascading use of raw materials and energy in the process of ecosystem functioning. The exchange of resources in cascading natural processes leads to the sustainability of ecosystems. This is achieved by reducing or eliminating the use of additional resources, energy, and waste disposal costs, which not only reduces pollution. There is no waste in natural ecosystems, as byproducts from one cycle become raw material for another process (Sakhuja, 2017).

The blue economy offers an alternative to traditional industrial processes, shifting the focus from the use of extractive resources to simpler and greener technologies. Its principles involve entrepreneurs in innovative business projects that can bring economic benefits, successfully competing with traditional approaches in the economy (Hotaling, 2021).

The European Union is the main initiator of the introduction and implementation of the blue economy. The EU is not limited to its own territory, but is also trying to implement it worldwide (Langlet, 2019).

Given the original definition of ecology as the science of natural economics, the unity of the public interests of ecology and economics, the presence of economic aspects in many environmental protection activities, the implementation of human economic activity through nature, attention to the economic component of modern ecology has increased significantly (Techera, 2019).
Another problem is the misalignment of the interests of the economy and the ecology, which results from the definition of the economic effect solely by the market sphere (Young, 2013). Natural goods, such as air, forests, and oceans, have no price, since they are not market values. Man's purely consumerist attitude toward nature causes a permanent conflict situation, characteristic of the history of all civilizations and almost tragic in our time. The problem of saving and restoring the environment has acquired the status of a leading economic problem. Thus, the economic aspect has become a reinforcing factor in the search for a compromise of common solutions in the interaction between society and nature.

\section{The blue economy and the peculiarities of the use of water resources}

It should be noted that the backbone of the blue economy should be technology and industries that cannot harm the oceans (Buono, 2021). That is, the main focus of the blue economy is on the world's oceans, seas, and everything connected with them (Rao, 2020). The problem of water use is not new. It is a problem of time that arose a long time ago (Craven, 1982; Sherman, 1986).

The hydrosphere is the totality of all water sources on the planet: oceans, seas, rivers, lakes, reservoirs, swamps, groundwater, glaciers, snow cover, atmospheric water vapor, etc. (Essen, 2020).

In 2019, the economic field related to the ocean, sea and coastal zone included almost 4.5 million people. The annual turnover of the "blue economy" is approaching 700 billion euros. According to European experts, this figure can be tripled in 10 years by introducing the latest technologies in the field of alternative energy and renewable food production.

Given the rate of growth of the world economy in recent years, it can be argued that global production and employment will grow over the next $10-15$ years, including a significant increase in the contribution of maritime industries. According to OECD experts, economic activity in the oceans could increase to $\$ 3$ trillion by 2030 , and the number of full-time workers could rise to nearly 40 million.

Water is a multifunctional element in the system of providing a normal full-fledged human life. Mankind consumes water resources in various ways to fully meet its vital needs. Along with other 
components, water is a human need provided by nature.

Water is an element of the environment. Currently, the environment is changing so rapidly that the human body does not always have time to adapt to its changes. The human-environment problem is recognized as an age-old problem. Its dissemination is aimed at determining in advance what exactly threatens human health in further interference with the environment.

Water is the most abundant substance on Earth, occupying more than $70 \%$ of the surface. Many kinds of organisms live in water, and the inhabitants of land also depend on it. Water is the main component of cells, a solvent, a means of transferring nutrients, and it is involved in biochemical reactions in organisms.

The reserves of water on Earth are enormous. However, it is mostly the salty water of the oceans. The reserves of fresh water, for which there is a great need, are insignificant and exhaustible. In many parts of the world, there is not enough water for irrigation, industry, drinking, and other household needs.

For a long historical period, humans fully met all their needs in water and did not feel its shortage. However, due to the rapid growth of the population on land and its productive activities, the demand for water has increased significantly. Today, it has reached such a scale that in many parts of the world, and especially in industrialized regions, there is an acute shortage of fresh water. According to experts, the demand for water will continue to grow. In recent years, it is estimated to have increased tenfold. In many countries, there are problems with water supply in large cities. Complex irrigation systems and technical facilities for water supply were used by man as early as 5,000 years ago (in ancient Egypt and Mesopotamia). However, even today, in many countries (African and Asian) only a small amount of water is supplied centrally through water supply networks (Roberts, 2016; Rudge, 2021).

The growing and largely uncontrolled use of water bodies and the constant pollution of the hydrosphere increase the risk of the depletion of water resources. Humans should radically change their attitude to the use of water. Mankind has already come too close to the line beyond which further economic growth, if it continues to be based on the consumer principles of water use, can upset the ecological balance of the planet (Golberg, 2020).

Pollution of water resources is a change in their physical, chemical and biological properties due to the ingress of harmful liquid, solid and gaseous substances that make water unsafe for use, damage the national economy and human health. Water not only has a direct physiological impact on plant growth and development, but also changes other important environmental factors.

The extent of water pollution is becoming threatening. There are many sources of water pollution. The main ones are:

- wastewater from industrial, municipal and agricultural enterprises;

- water from boreholes, oil fields, mines;

- industrial waste from the extraction of various minerals;

- wood waste from the woodworking industry; discharges from water and railroad transport, etc.

Among all sources of water pollution, industrial wastewater occupies an important place. The largest polluters of surface and ground water are: chemical industry, ferrous and non-ferrous metallurgy, coke-chemical industry, heavy, power and transport machine building, municipal and agriculture (Payoyo, 1994).

The most important consequence of water pollution is that when pollutants enter water bodies, they cause a decrease in water quality (Hennessey, 2005). This is manifested in changes in its physical properties (transparency, odor, taste) and chemical composition (reaction, amount of organic and mineral impurities, toxic substances, etc.), in reduction of oxygen content in water, changes in number and species composition of microorganisms, appearance of pathogenic bacteria. Thus, the pollution of natural waters can lead to the fact that they become unsuitable for drinking, bathing, and sometimes for technical purposes. As a rule, polluted water is unsuitable for use in industry, because it disturbs the normal course of the technological process and reduces the quality of products.

Natural water contaminated by domestic sewage is unsuitable for the water supply because the harmful substances and pathogens it contains are very harmful to human health and can cause various infectious diseases (dysentery, infectious hepatitis, cholera, etc.). As a result of physical, chemical and thermal pollution of rivers, lakes and reservoirs, their regime is disturbed. Due 
to nitrogen and phosphorus inflow, biogenic processes are accelerated, which is called anthropogenic eutrophication.

The result of increasing anthropogenic pressure on the ocean ecosystem is the gradual degradation of marine biocenoses with the consequent negative impact on human health. Ensuring ecological balance and full meeting of population and public economic needs for water is possible by improving water quality and water regime of rivers, rational use of water by enterprises of all sectors of public economy and reproduction of water resources.

The problems of pollution of the hydrosphere are global in nature. Therefore, at the present stage, international cooperation is important in solving it. The first small step in this direction was taken 20 years ago, when 12 European countries signed the Convention banning the dumping of toxic waste from ships into the Atlantic Ocean.

The most important consequence of water pollution is that when pollutants enter water bodies, they cause a decrease in water quality. This manifests itself in changes in its physical properties (transparency, odor, taste) and chemical composition (reaction, amount of organic and mineral impurities, toxic substances, etc.), in reduction of oxygen content in water, changes in number and species composition of microorganisms, appearance of pathogenic bacteria. Thus, the pollution of natural waters can lead to the fact that they become unsuitable for drinking, bathing, and sometimes for technical purposes. As a rule, polluted water is unsuitable for use in industry, because it disturbs the normal course of the technological process and reduces the quality of products (Lambert, 2019).

Natural water contaminated by domestic sewage is unsuitable for public water supply, because the harmful substances and pathogens it contains are very harmful to human health and can cause various infectious diseases.

Wastewater from the pulp and paper industry containing organic substances that, when oxidized, absorb oxygen from the water, giving the water an unpleasant taste and smell and changing its color.

Phenolic compounds entering water bodies with wastewater from the timber and chemical industry, coke chemistry, various enterprises engaged in processing of agricultural raw materials, and others, affect the regime of nutrients and dissolved gases (oxygen, carbon monoxides), give the water a pungent smell.

Mercury, heavy metals under the influence of certain microorganisms in the aquatic environment are converted into highly toxic substances that accumulate in plankton, benthos, fish and through food chains get into the human body, negatively affecting individual organs and the body as a whole.

Pollution of water with petroleum products is especially dangerous. By covering the water with a thin film, oil prevents oxygen from penetrating into the water, causing great harm to the inhabitants of the water body and often leading to their mass death. Petroleum kills fish, crustaceans, and many other animals. If fish are still alive after oil pollution, they should not be eaten because they have a strong petroleum odor and an unpleasant taste. Millions of waterfowl are killed by oil each year.

Construction of dams, installation of shallow artificial ponds, thermal pollution can be causes of water bloom, which occurs due to rapid and intensive development of blue-green algae. When the algae die off, the entire surface of the water is often covered with a slimy film. Its decomposition produces such dangerous toxic substances as phenol, indole, etc. The water becomes unsuitable not only for drinking, but also for bathing.

As a result of physical, chemical and thermal pollution of rivers, lakes and reservoirs, their regime is disturbed. Due to nitrogen and phosphorus inflow, biogenic processes are accelerated, which is called anthropogenic eutrophication. Redox-processes in water change in an undesirable direction, it begins to "rot", acquires the smell of ammonia and methane. Black sticky deposits of hydrogen sulfide accumulate at the bottom of water bodies. This leads to a decrease in the productivity of reservoirs, deterioration of recreation conditions for people, and an increase in the cost of water treatment systems for cities and industrial enterprises.

Ecology and environmental management problems are usually associated with the activities of industrial enterprises. However, many natural resources are directly or indirectly used in our lives. The problem of resource consumption at home is very important and deserves serious attention.

Thus, the problem of rational use of natural resources in the sphere of consumption is a complex 
socio-economic problem, which can be solved by a set of measures that can be divided into two groups:

1) measures of economic regulation;

2) measures to regulate consumption through a system of educational activities for resource awareness.

In real life, these actions are interrelated and interdependent. For example, the introduction of new, improved technical solutions to save resources must be accompanied by their promotion and the creation of conditions for their use.

One of the most used resources in everyday life is water. Its largest consumer after industry and agriculture is the housing and utilities sector. Water creates comfortable living conditions for people (therefore, it is possible to use showers, bathtubs, washing machines, washing cars, etc.). Per capita water consumption is a barometer of people's standard of living (South, 1993).

A modern city consumes 300-500 liters of water per person per day, which significantly exceeds the minimum norm of 25 liters. It is impossible to solve the problem of rational consumption of drinking water without conscious attitude of each person to it. About $20 \%$ of drinking water goes into the sewer system without use. Most often, water losses are due to technical reasons, and often drinking water is not used for its intended purpose (for example, it is reasonable to use untreated water for irrigation of green spaces in cities).

According to the United Nations, about 250 million people today do not have quality drinking water, in particular, one person in North America consumes on average 70-75 times more water than a person in Central Africa (United Nations, 2011). Nearly $70 \%$ of all freshwater used worldwide is used for irrigation, and half of it is lost before it reaches the plant root system.

The basis for improving the material well-being of people is social production. However, with its growth, society faces an aggravation of the ecological situation, namely, depletion of natural resources, environmental pollution, deterioration of the physical and moral condition of people, and the loss of human connection with nature. These losses cannot be compensated by an increase in the consumption of material goods provided by production.

Material values that meet the needs of the population are significantly different from the material values of the production sphere. Therefore, the ways of transition to non-waste type of consumption have material and economic peculiarities. Primarily, all service industries have a much lower level of manufacturability as a result of the absence of waste. The amount of waste from individual enterprises and specific consumers is insignificant, and in addition, this waste is very heterogeneous and multi-component. In addition, the sphere of consumption is difficult to regulate economically, because the need to improve people's standard of living does not depend on saving even the most scarce resources. It should also be borne in mind that the sphere of consumption is always focused on specific consumers, who live according to numerous national traditions, have a certain level of culture and so on.

\section{Conclusions}

Modern society is in an ecological crisis, the overcoming of which objectively requires increased attention to the environment. The worsening of the crisis itself cannot be considered the result of individual mistakes, miscalculations, or a wrongly chosen social development strategy. It reflects a profound crisis of culture, which has encompassed the entire complex of interaction between society and nature, and through the development of science, technology, and production has become so tangible that its impact is limitless and chaotic. The incompetent use of nature has led to a system of conflicts. Many of them are rooted in the history of mankind. However, only the unprecedented development of productive forces under conditions of competition, the lack of knowledge about nature aggravated them, gave them a global character.

At present, overcoming the crisis becomes possible only by overcoming human alienation from nature, by recognizing the primacy of the ecological imperative, by abandoning the attitude of unlimited progress, by harmonizing economic expansion and ecological limits. No technical or social achievements will contribute to human life if they contradict the laws of nature.

Today human beings are faced with the need to carry out safe ecological development. For this it is necessary for them to have new knowledge about the environment, new resource-saving and waste-free technologies, new norms of behavior, which in general provide a high level 
of ecological culture. It is impossible to use and protect nature without knowing its structure and laws of development, without taking into account the maximum allowable pressures on ecosystems, at which society can afford not to destroy them.

The basis for improving the material well-being of people is social production. However, with its growth, society faces the depletion of natural resources, environmental pollution, deterioration of the physical and moral condition of people, and the loss of human connection with nature. These losses cannot be compensated by an increase in the consumption of the material goods provided by production.

In a market economy, the environment is still a free good. As long as the prices of raw materials and products do not include the value of used or polluted air, water, and land resources, these resources will continue to be irrationally exploited, and pollution levels will increase.

Economists do not have to develop new technologies, but they can calculate and justify the impact of certain technologies on the environmental impact of production. In particular, to make changes in the practice of calculating the cost of projects and possible profits, to establish maximum permissible loads on the environment, and to apply the "polluter pays" principle more widely.

At present, the effectiveness of the environmental and economic policy of the state can be formed on the basis of three basic principles:

- minimization of anthropogenic transformations;

- gradual elimination of the negative effects of anthropogenic transformations;

- selective approach to environmental measures to improve its effectiveness.

\section{References:}

Brears, R. C. (2021). Developing the Blue Economy. Cham, Switzerland: Springer Nature, 337 p.

Buono, A., Li, Y., \& Paes, R. L. (2021). Remote Sensing of the Oceans: Blue Economy and Marine Pollution. MDPI AG, $224 \mathrm{p}$.

Craven, J. P., \& Cleveland, H. (1982). The management of Pacific marine resources: present problems and future trends. Boulder: Westview Press, xix, $105 \mathrm{p}$.

Essen, E. (2020). Blue Economy. The new frontier for marine environmental protection and sustainable development. München: GRIN Verlag, $36 \mathrm{p}$.

Golberg, A. (2020). Macroalgal biorefineries for the blue economy. New Jersey: World Scientific, xvi, $288 \mathrm{p}$.

Hennessey, T. M., \& Sutinen, J. G. (2005). Sustaining large marine ecosystems: the human dimension. San Diego: Elsevier Science, xii, 368 p.

Hotaling, L., Spinrad, R. W., \& Head, M. K. (2021). Preparing a workforce for the new blue economy: people, products and policies. Amsterdam; Oxford; Cambridge: Elsevier, lvii, 575 p.

Lambert, N., Turner, J., \& Hamflett, A. (2019). Technology and the blue economy: from autonomous shipping to big data. London: Kogan Page, xiv, $272 \mathrm{p}$.

Langlet, D., \& Rayfuse, R. (2019). The ecosystem approach in ocean planning and governance: perspectives from Europe and beyond. Leiden: Brill Nijhoff, xxiii, $466 \mathrm{p}$.

Nash, J., \& Herscovitch, B. (2018). The blue economy: national, regional and global perspectives. Fyshwick, Australian Capital Territory: Sea Power Centre Australia, x, 47 p.

Pauli, G. (2010). The Blue Economy: 10 Years, 100 Innovations, 100 Million Jobs. Taos, New Mexico: Paradigm Publications, xxxii, 308 p.

Payoyo, P. B. (1994). Ocean governance: sustainable development of the sea. Tokyo: United Nations University Press, xlv, $369 \mathrm{p}$.

Rao, I. A. (2020). Elements of blue economy. Islamabad: IPS Press, $\mathrm{xx}, 288 \mathrm{p}$.

Roberts, J., \& Ali, A. (2016). The Blue Economy and Small States. London: Commonwealth Secretariat, $50 \mathrm{p}$.

Rudge, P. (2021). Beyond the blue economy: creative industries and sustainable development in small island developing states. London; New York: Routledge, $171 \mathrm{p}$.

Sakhuja, V., \& Narula, K. (2017). The blue economy: concept, constituents and development. New Delhi: Pentagon Press, xxiv, 224 p.

Sherman, S., \& Alexander, L. M. (1986). Variability and management of large marine ecosystemss. Boulder: Westview Press, xxvi, 319 p. 
South, G. R., \& Rao, G. (1993). Marine resources and development. Suva, Fiji: PIMRIS, University of South Pacific Library, v, 149 p.

Techera, E. J., \& Winter, G. (2019). Marine extremes: ocean safety, marine health and the blue economy. Abingdon, Oxon: Routledge, an imprint of the Taylor \& Francis Group, xxi, 231 p.

United Nations (2011). Ecosystem approaches to the management of ocean-related activities: building on integrated coastal management to enhance the resilience of marine ecosystems to stressors, such as climate change: training manual. New York: United Nations, $\mathrm{xx}, 275 \mathrm{p}$.

Young, M. D., \& Esau, C. (2013). Investing in water for a green economy: services, infrastructure, policies, and management. Abingdon, Oxon: Routledge, $\mathrm{xx}, 271 \mathrm{p}$. 